\title{
ANALISIS KEBUTUHAN RUANG TERBUKA HIJAU (RTH) DI KAWASAN KOTA LAMA KOTA KUPANG
}

\author{
Aplimon Jerobisonif ${ }^{1}$, Ariency K. A. Manu
}

\begin{abstract}
Abstrak :
Perkembangan kota yang terjadi di Kota Kupang terlihat dengan semakin berkembangnya perekonomian di segala sektor. Perdagangan dan jasa juga memegang peranan penting dalam meningkatkan pertumbuhan perekonomian. Bertambahnya tingkat pertumbuhan penduduk juga merupakan dampak dari suatu perubahan kota yang menunjukkan banyaknya aktivitas yang terjadi di dalam kota tersebut yang pada akhirnya membutuhkan lahan yang banyak untuk permukiman. Perkembangan kota juga akan mengakibatkan konversi terhadap lahan-lahan hijau, sehingga peran lahan hijau tersebut menjadi prioritas

Penelitian ini betujuan untuk : 1). Menganalisis luas dan sebaran ruang terbuka hijau di Kota Lama Kota Kupang; 2). Menganalisis jumlah kebutuhan ruang terbuka hijau di Kota Lama Kota Kupang berdasarkan luas kawasan, jumlah penduduk, dan karbon dioksida yang dihasilkan; 3). Mengidentifikasi apakah luas dan sebaran RTH di Kota Lama Kota Kupang telah sesuai terhadap kebutuhan luas kawasan hijau berdasarkan: (a). persentase luas (Permendagri No. 1 tahun 2007 dan Peraturan Menteri Pekerjaan Umum No.05/PRT/M/2008); (b). luasan perkapita (Simonds, 1983); dan (c). isu penting pada suatu kota; 4) Mengidentifikasi kesesuaian jumlah dan sebaran RTH berdasarkan Masterplan RTH Kota Kupang terhadap Kondisi RTH di Kota Lama; 5) Model Pengembangan ruang terbuka hijau untuk memenuhi kebutuhan RTH di Kota Lama Kota Kupang,

Penelitian ini menggunakan pendekatan deskriptif dengan menganalisis data-data biofisik berupa luas wilayah, data jumlah penduduk, dan jumlah kendaraan di Kota Kupang untuk merumuskan model pengembangan RTH.

Kondisi Eksisting RTH yang terdapat di Kelurahan LLBK hanya terdiri dari : a) RTH Publik berupa : Taman kota pantai Kopan, Taman Tugu- Terminal, Halaman Gereja Kota Kupang, Parkiran terbuka Jalan Siliwangi, Sempadan Pantai, Sempadan Sungai. Luasan RTH Publik mencapai 0,14 Ha atau sebesar 11,29 \% dari luas Kawasan Kota Lama. Sedangkan berdasarkan pedoman dari UU no. 26 tahun 2007 maka luas RTH Publik yang dibutuhkan sebesar 20\% adalah $\mathbf{0 , 2 4} \mathbf{H a}$; b). RTH Privat : Pekarangan seluas $745 \mathrm{~m}^{2}$ dan Taman Atap sebesar $200 \mathrm{~m}^{2}=945 \mathrm{~m}^{2}$ atau $\mathbf{0 , 0 9 1}$ Ha atau sebesar $\mathbf{7 , 2 5 \%}$ dari luas Kawasan Kota Lama. Sedangkan berdasarkan pedoman dari UU no. 26 tahun 2007 maka luas RTH Privat yang dibutuhkan sebesar 10\% adalah seluas 0,12 Ha.

Hasil Analisis kebutuhan luasan RTH Kawasan Kota Lama didapat kebutuhan RTH berdasarkan Luas wilayah adalah sebesar 0,37 Ha, berdasarkan Jumlah Penduduk adalah sebesar 0,18 Ha, berdasarkan Kebutuhan Oksigen adalah sebesar 0,38 Ha, berdasarkan Netralisasi Karbon Dioksida adalah sebesar 1,05 Ha.
\end{abstract}

Kata kunci : Ruang Terbuka Hijau, Kebutuhan RTH, Kawasan Kota lama.

Jerobisonif', $\mathbf{M a n u}^{2}$, Adalah Dosen Jurusan Teknik Arsitektur, Fakultas Sains dan Teknik Undana 


\section{\begin{tabular}{l|l}
94 & JUTEKS Jurnal Teknik Sipil
\end{tabular}}

\section{PENDAHULUAN}

\subsection{Latar Belakang}

Hardiansah dan Dhani (2011) mengungkapkan bahwa memasuki dekade kedua abad 21, kota-kota Indonesia mengalami berbagai persoalan yang berujung pada menurunnya kualitas lingkungan perkotaan. Permasalahan lingkungan, sosial, kependudukan, infrastruktur, lapangan kerja, dan lain sebagainya merupakan isu perkotaan yang seringkali bermunculan di ruang publik, baik dalam bentuk media ataupun diseminasi publik. Selain persoalan yang bersifat fisik, kota-kota Indonesia juga menghadapi persoalan tata kelola manajemen perkotaan yang tidak efisien. Banyak kota juga mengalami permasalahan tidak memadainya kualitas tata kelola kawasan perkotaan yang disebabkan oleh minimnya kapasitas kelembagaan dan SDM.

Pemanfaatan lahan kota yang terus tumbuh dan bersifat akseleratif untuk pembangunan berbagai fasilitas perkotaan (termasuk kemajuan teknologi, industri dan transportasi), sering mengubah konfigurasi alami lahan/bentang alam perkotaan, menyita ketersediaan lahan dan berbagai bentuk ruang terbuka lainnya. Hal ini dapat mengurangi ketersediaan Ruang Terbuka Hijau (RTH) yang biasanya dianggap sebagai lahan yang tidak ekonomis.

Permasalahan juga terlihat di kawasan Kota Lama Kota Kupang, yang dari segi sejarah merupakan kawasan dengan kategori kota peninggalan kolonial. Sehingga kawasan ini memiliki potensi nilai/makna kesejarahan yang harus dilestarikan. Dari segi letak geografis, Kawasan Kota Lama terbentang sepanjang pesisir pantai teluk Kupang yang juga merupakan pusat kota lama yang menjadi cikal bakal terbentuk Kota Kupang. Untuk mengatasi permasalahan tersebut perlu dilakukan suatu cara untuk penanggulangan kerusakan lingkungan akibat dari permasalahan-permasalahan lingkungan yang timbul. Salah satu cara yang bisa dilakukan untuk mengatasi kerusakan lingkungan perkotaan adalah dengan menganalisis kebutuhan RTH yang tepat dan sesuai fungsinya.

\section{Volume 2 Nomor 1 April 2017}

RTH dengan fungsi yang terkait dengan keberadaannya (fungsi ekologis, sosial, ekonomi, dan arsitektural) dan nilai estetika yang dimilikinya (obyek dan lingkungan) tidak hanya dapat dalam meningkatkan kualitas lingkungan dan untuk kelangsungan kehidupan perkotaan tetapi juga dapat menjadi nilai kebanggaan dan identitas kota. Untuk mendapatkan RTH yang fungsional dan estetik dalam suatu sistem perkotaan maka luas minimal, pola dan struktur, serta bentuk dan distribusinya harus menjadi pertimbangan dalam membangun dan mengembangkannya

Keberadaan RTH penting dalam mengendalikan dan memelihara integritas dan kualitas lingkungan. Pengendalian pembangunan wilayah perkotaan harus dilakukan secara proporsional dan berada dalam keseimbangan antara pembangunan dan fungsi-fungsi lingkungan. Kelestarian RTH suatu wilayah perkotaan harus disertai dengan ketersediaan dan seleksi tanaman yang sesuai dengan arah rencana dan rancangannya.

\subsection{Tujuan dan Manfaat Penelitian \\ 1.3.1. Tujuan Penelitian}

Tujuan dari penelitian ini adalah :

1.Menganalisis jumlah kebutuhan ruang terbuka hijau di Kota Lama Kota Kupang berdasarkan luas kawasan, jumlah penduduk, dan karbon dioksida yang dihasilkan.

2.Mengidentifikasi kebutuhan luas dan sebaran RTH di Kota Lama Kota Kupang telah sesuai terhadap kebutuhan luas kawasan hijau berdasarkan: (1). persentase luas (Permendagri No.1 tahun 2007 dan Peraturan Menteri Pekerjaan Umum No.05/PRT/M/2008); (2). luasan perkapita (Simonds, 1983); dan (3). isu penting pada suatu kota.

\subsubsection{Manfaat Penelitian}

Manfaat dari penelitian ini adalah :

1.Memberikan informasi kepada Pemerintah Daerah Kota Kupang mengenai kebutuhan ruang terbuka hijau di Kota Lama 
2.Sebagai bahan pertimbangan bagi Pemerintah Daerah Kota Kupang untuk menentukan lokasi dan luas kawasan hijau kota.

3.Sebagai bahan rujukan dan perbandingan untuk penentuan kebutuhan ruang terbuka hijau khususnya bagi kawasan-kawasan kota yang mengalami permasalahan lingkungan yang sama.

\section{METODE PENELITIAN}

\subsection{Lokasi Penelitian}

Lokasi penelitian berada pada Kawasan Kota Lama dan secara administratif berada di Kelurahan LLBK, Kelurahan Bonipoi dan Kelurahan Solor.

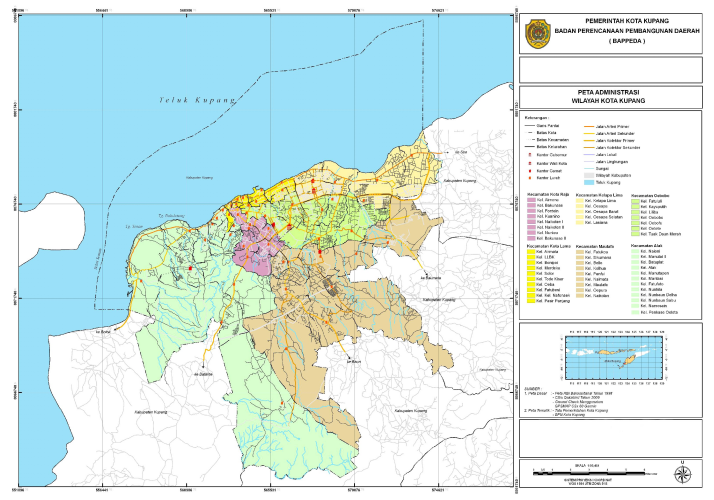

Gambar 1. Letak lokasi

di Wilayah Kota Kupang

Sumber : Bappeda Kota Kupang, 2010

\subsection{Koleksi Data}

Data yang digunakan dalam penelitian ini meliputi data biofisik berupa luas wilayah, data jumlah penduduk, dan jumlah kendaraan di Kota Kupang yang diperoleh dari Badan Pusat Statistik (BPS) Kota Kupang.

\subsection{Analisis Data}

Data yang dikumpulkan akan dianalisis berdasarkan :

\subsubsection{Penyediaan RTH Berdasarkan Luas} wilayah di perkotaan.

Pedoman penyediaan RTH dikawasan perkotaan diatur dalam Peraturan Menteri
Pekerjaan Umum Nomor:05/PRT/M/2008 yang menjelaskan sebagai berikut:

1.Ruang terbuka hijau di perkotaan terdiri dari RTH Publik dan RTH privat;

2.Proporsi RTH pada wilayah perkotaan adalah sebesar minimal $30 \%$ yang terdiri dari $20 \%$ ruang terbuka hijau publik dan $10 \%$ terdiri dari ruang terbuka hijau privat;

3.Apabila luas RTH baik publik maupun privat di kota yang bersangkutan telah memiliki total luas lebih besar dari peraturan atau perundangan yang berlaku, maka proporsi tersebut harus tetap dipertahankan keberadaannya.

Proporsi 30\% merupakan ukuran minimal untuk menjamin keseimbangan ekosistem kota, baik keseimbangan sistem hidrologi dan keseimbangan mikroklimat, maupun sistem ekologis lain yang dapat meningkatkan ketersediaan udara bersih yang diperlukan masyarakat, serta sekaligus dapat meningkatkan nilai estetika kota.

Target luas sebesar 30\% dari luas wilayah kota dapat dicapai secara bertahap melalui pengalokasian lahan perkotaan secara tipikal.

3.3.2. Penyediaan RTH Berdasarkan Jumlah Penduduk

Untuk menentukan luas RTH berdasarkan jumlah penduduk, dilakukan dengan mengalikan antara jumlah penduduk yang dilayani dengan standar luas RTH perkapita sesuai peraturan yang berlaku (Peraturan Menteri Pekerjaan Umum No.05/PRT/M/2008)

\subsubsection{Penyediaan RTH Berdasarkan Kebutuhan} Fungsi Tertentu.

Fungsi RTH pada kategori ini adalah untuk perlindungan atau pengamanan, sarana dan prasarana misalnya melindungi kelestarian sumber daya alam, pengaman pejalan kaki atau membatasi perkembangan penggunaan lahan agar fungsi utamanya tidak terganggu.

RTH kategori ini meliputi: jalur hijau sempadan rel kereta api, jalur hijau jaringan listrik tegangan tinggi, RTH kawasan perlindungan setempat berupa RTH sempadan sungai, RTH sempadan pantai, dan RTH pengamanan sumber air baku/mata air. 


\section{JUTEKS Jurnal Teknik Sipil Volume 2 Nomor 1 April 2017}

\subsubsection{Penyediaan kebutuhan RTH Berdasarkan Kebutuhan Oksigen.}

Kebutuhan oksigen yang dimaksud adalah oksigen yang digunakan oleh manusia, ternak dan kendaraan bermotor. Untuk mengetahui kebutuhan oksigen di suatu areal perkotaan maka perlu mengetahui jumlah penduduk yang ada. Kebutuhan oksigen untuk manusia dapat dihitung dengan asumsi bahwa manusia mengoksidasi 3000 kalori per hari dari makanan dan menggunakan sekitar 600 liter oksigen dan memproduksi sekitar 480 liter $\mathrm{CO}_{2}$ (Dewi, 2008)

Kebutuhan RTH kota berdasarkan kebutuhan oksigen dapat dihitung berdasarkan pendekatan Metode Gerakis (Dewi, 2008) yang didasarkan proses fotosintesis dijelaskan dengan persamaan berikut:

$$
\mathrm{Lt}=\frac{(54)(0,9375)}{\mathrm{Xt}+\mathrm{Yt}} \mathrm{m}^{2}
$$

Kemudian dikembangkan oleh Wijayanti (Dewi, 2008) yaitu sebagai berikut :

$$
\mathrm{Lt}=\frac{(\mathrm{Pt}+\mathrm{Kt}+\mathrm{Tt})}{(54)(0,9375)} \mathrm{m}^{2}
$$

Keterangan :

Lt : Luas RTH pada tahun $\mathrm{t}\left(\mathrm{m}^{2}\right)$

$\mathrm{Xt}, \mathrm{Pt}$ : Jumlah kebutuhan oksigen bagi penduduk pada tahun $\mathrm{t}$

Yt, Kt : Jumlah kebutuhan oksigen bagi kendaraan bermotor pada tahun $\mathrm{t}$

$\mathrm{Tt} \quad$ : Jumlah kebutuhan oksigen bagi ternak pada tahun $\mathrm{t}$

54 : Konstanta yang menunjukkan $1 \mathrm{~m}^{2}$ luas lahan menghasilkan 54 gram berat kering tanaman perhari

0,9375 : Konstanta yang menunjukkan 1 gram berat kering tanaman adalah setara dengan produksi oksigen 0,9375 gram

Kebutuhan oksigen untuk kendaraan bermotor dihitung berdasarkan konsumsi bahan bakar minyak (bensin dan solar) oleh tiap-tiap jenis kendaraan bermotor per harinya, yaitu sepeda motor dan kendaraan penumpang menggunakan bensin, sedangkan bus dan kendaraan beban menggunakan solar. Untuk kebutuhan oksigen tiap $1 \mathrm{Kg}$ bensin yaitu 2.77 $\mathrm{kg}$ dan untuk $1 \mathrm{Kg}$ solar yaitu $2.88 \mathrm{Kg}$ (Muis 2005 dalam Permen PU No. 05/PRT/M/2008).

Konsumsi bensin oleh sepeda motor sebesar 1.5 liter/hari dan kendaraan penumpang sebesar 25 liter/hari. Sedangkan konsumsi solar oleh bus sebesar 50 liter/hari dan kendaraan beban sebesar 40 liter/hari .

Untuk menghitung populasi penduduk, ternak, dan kendaraan bermotor dari tahun 2015 hingga 2025 digunakan rumus bunga berganda (Pancawati, 2010) yaitu :

$\mathrm{P}_{\mathrm{t}+\mathrm{x}}=\mathrm{P}_{\mathrm{t}}(1+\mathrm{r})^{\mathrm{x}}$

Keterangan :

$\mathrm{P}_{\mathrm{t}+\mathrm{x}}$ : Jumlah penduduk pada tahun $(\mathrm{t}+\mathrm{x})$

$\mathrm{P}_{\mathrm{t}}$ : Jumlah peduduk pada tahun ( $\mathrm{t}$ )

$r$ : Rata-rata persentase pertabahan jumlah penduduk

$\mathrm{x}$ : Selisih tahun

Rata-rata persentase pertambahan jumlah penduduk dapat dicari dengan menggunakan persamaan berikut :

Keterangan :

t1 : Jumlah penduduk tahun ke-1

t2 : Jumlah penduduk tahun ke-2

Rumus bunga berganda juga dapat digunakan untuk memprediksi jumlah ternak dan kendaraan bermotor untuk masing-masing jenisnya dengan menggunakan data jumlah dan laju pertumbuhan pada tahun sebelumnya.

\subsubsection{Kebutuhan RTH Berdasarkan Netralisasi} Karbon Dioksida.

RTH juga memiliki fungsi sebagai penyerap karbon dioksida (CO2), namun harus diperhatikan jenis RTH yang dapat memaksimalkan fungsi ini adalah RTH hutan kota. Cahaya matahari yang memancar sepanjang hari akan dimanfaatkan oleh vegetasi dalam fotosintesis yang berfungsi untuk mengubah gas $\mathrm{CO} 2$ dari $\mathrm{H} 2 \mathrm{O}$ menjadi Karbohidrat dan Oksigen (O2). Proses ini sangat berguna bagi manusia, sebab bila konsentrasi $\mathrm{CO} 2$ meningkat akan beracun bagi manusia dan menyebabkan efek rumah kaca (green-house effect). 


\subsubsection{Kebutuhan RTH Berdasarkan Perhi- tungan Kebutuhan Air.}

Kebutuhan air dalam kota tergantung dari faktor kebutuhan air bersih pertahun, jumlah air yang dapat disediakan oleh PAM, potensi air saat ini, dan kemampuan RTH menyimpan air. Berdasarkan angka kebutuhan air tersebut lebih lanjut dapat dihitung luas RTH kota yang dibutuhkan untuk mencukupi kebutuhan air masyarakat kota.

Standar kebutuhan dan alokasi RTH ditetapkan untuk menentukan luas RTH yang dibutuhkan di masa yang akan datang berdasarkan pada peningkatan jumlah penduduk (Permen PU Nomor 05/PRT/M/2008). Kebutuhan air dalam kota tergantung dari faktor:

a. Kebutuhan air bersih per tahun

b.Jumlah air yang dapat disediakan oleh PAM

c. Potensi air saat ini

d.Kemampuan hutan menyimpan air

Faktor-faktor di atas dapat ditulis dalam persamaan :

$L=\frac{\operatorname{PoK}(1+r-c) t-P A M-P a}{Z}$

Dimana :

L : Luas hutan yang diperlukan untuk mencukupi kebutuhan air (dalam $\mathrm{Ha}$ )

Po : Jumlah penduduk kota pada tahun ke $\mathrm{O}$

$\mathrm{K}$ : Konsumsi air per kapita (liter/hari)

$\mathrm{R}$ : Laju kebutuhan air bersih (biasanya seiring dengan laju pertambahan penduduk kota setempat

$\mathrm{t}$ : Tahun

c : faktor koreksi (besarnya tergantung dari upaya pemerintah dalam penurunan lajupertumbuhan penduduk)

PAM : Kapasitas suplai air oleh PAM (dalam $\mathrm{m}^{3} /$ tahun)

$\mathrm{Pa} \quad$ : Potensi air tanah saat ini

\section{III.HASIL DAN PEMBAHASAN}

\subsection{Arahan Penyediaan RTH}

3.1.1. Pada Bangunan/Perumahan

1.RTH Pekarangan

a.Pekarangan rumah besar

Ketentuan penyediaan RTH untuk pekarangan rumah besar adalah sebagai berikut:

- Kategori yang termasuk rumah besar adalah rumah dengan luas lahan diatas 500 meter persegi

- Ruang Terbuka Hijau Minimum yang diharuskan adalah luas lahan $\left(\mathrm{m}^{2}\right)$ dikurangi luas dasar bangunan $\left(\mathrm{m}^{2}\right)$ sesuai peraturan setempat.

- Jumlah pohon pelindung yang harus disediakan minimal 3 pohon pelindung ditambah dengan perdu dan semak serta penutup tanah atau rumput.

b.Pekarangan rumah sedang

Ketentuan penyediaan RTH untuk pekarangan rumah sedang adalah sebagai berikut:

- Kategori yang termasuk rumah sedang adalah rumah dengan luas lahan antara 200 sampai dengan 500 meter persegi

- Ruang Terbuka Hijau Minimum yang diharuskan adalah luas lahan $\left(\mathrm{m}^{2}\right)$ dikurangi luas dasar bangunan $\left(\mathrm{m}^{2}\right)$ sesuai peraturan setempat.

- Jumlah pohon pelindung yang harus disediakan minimal 2 pohon pelindung ditambah dengan perdu dan semak serta penutup tanah atau rumput.

c. Pekarangan rumah Kecil

Ketentuan penyediaan RTH untuk pekarangan rumah besar adalah sebagai berikut:

- Kategori yang termasuk rumah kecil adalah rumah dengan luas lahan dibawah 200 meter persegi.

- Ruang Terbuka Hijau Minimum yang diharuskan adalah luas lahan $\left(\mathrm{m}^{2}\right)$ dikurangi luas dasar bangunan $\left(\mathrm{m}^{2}\right)$ sesuai peraturan setempat. 


\section{\begin{tabular}{l|llll}
98 & JUTEKS Jurnal Teknik Sipil Volume 2 & Nomor 1 April 2017
\end{tabular}}

- Jumlah pohon pelindung yang harus disediakan minimal 1 pohon pelindung ditambah dengan perdu dan semak serta penutup tanah atau rumput.

Keterbatasan luas halaman dengan jalan lingkungan yang sempit tidak menutup kemungkinan untuk mewujudkan RTH melalui penanaman dengan menggunakan pot atau media tanaman lainnya.

2.RTH halaman perkantoran, pertokoan dan tempat usaha.

RTH halaman perkantoran, pertokoan dan tempat usaha umumnya berupa jalur trotoar dan area parkir terbuka.

Penyediaan RTH pada kawasan ini adalah sebagai berikut :

a. Untuk dengan tingkat KDB 70\% - 90\% perlu menambahkan tanaman dalam pot

b.Perkantoran, pertokoan dan tempat usaha dengan $\mathrm{KDB}$ diatas $70 \%$ memiliki minimal 2 pohon kecil atau sedang yang ditanam pada lahan atau pot berdiameter 60 centimeter.

c. Persyaratan penanaman pohon pada perkantoran, pertokoan dan tempat usaha dengan KDB dibawah $70 \%$ berlaku seperti persyaratan pada RTH pekarangan rumah, dan ditanam pada area diluar KDB yang telah ditentukan.

3.RTH dalam bentuk Taman Atap Bangunan (Roof Garden).

Pada kondiri luas lahan terbuka terbatas, maka RTH dapat memanfaatkan ruang terbuka non hijau, seperti atap gedung, teras rumah, terasteras bangunan bertingkat dan disamping bangunan dan lain-lain dengan memakai media tambahan, seperti pot dengan berbagai ukuran sesuai lahan yang tersedia.

Lahan dengan KDB diatas 90\% seperti pada kawasan pertokoan di pusat kota, atau pada kawasan-kawasan dengan kepadatan tinggi dengan lahan yang sangat terbatas, RTH dapat disediakan pada atap bangunan. Untuk itu bangunan harus memiliki struktur atap yang secara teknis memungkinkan. Aspek yang harus diperhatikan dalam pembuatan taman atap bangunan adalah:
1) Struktur bangunan

2) Lapisan kedap air (waterproofing)

3) Sistem utilitas bangunan

4) Media tanam

5) Pemilihan material

6) Aspek keselamatan dan keamanan

7) Aspek pemeliharaan

- Peralatan

- Tanaman

Tanaman untuk RTH dalam bentuk taman atap bangunan adalah tanaman yang tidak terlalu besar, dengan pekarangan yang mampu tumbuh dengan baik pada media tanam yang terbatas, tanah terhadap hembusan angin serta relatif tidak memerlukan banyak air.

\subsubsection{Pada Lingkungan/Permukiman.}

\section{RTH Taman Rukun Tetangga}

Taman Rukun Tetangga (RT) adalah taman yang ditunjukkan untuk melayani penduduk dalam lingkup 1 (satu) RT, khususnya untuk melayani kegiatan sosial di lingkungan RT tersebut. Luas taman ini adalah minimal 1 meter persegi per penduduk RT, dengan luas minimal 250 meter persegi. Lokasi taman berada pada radius kurang dari 300 meter dari rumah-rumah penduduk yang dilayani.

Luas area yang ditanami tanaman (Ruang Hijau) minimal $70 \%-80 \%$ dari luas taman. Pada taman ini selain ditanami dengan berbagai tanaman, juga terdapat minimal 3 (tiga) pohon pelindung dari jenis pohon kecil atau sedang.

2.RTH Taman Rukun Warga.

RTH Taman Rukun Warga (RW) dapat disediakan dalam bentuk taman yang ditujukan untuk melayani penduduk satu RW, khususnya kegiatan remaja, kegiatan olahraga masyarakat, serta kegiatan masyarakat lainnya dilingkungan RW tersebut. Luas taman ini minimal 0,5 meter persegi per penduduk RW, dengan luas minimal 1.250 meter persegi. Lokasi taman berada pada radius kurang dari 1000 meter dari rumah-rumah penduduk yang dilayaninya.

Luas area yang ditanami tanaman (ruang hijau) minimal seluas $70 \%-80 \%$ dari luas 
taman, sisanya dapat berupa pelataran yang diperkeras sebagai tempat melakukan berbagai aktivitas. Pada taman ini selain ditanami dengan berbagai tanaman sesuai keperluan, juga terdapat minimal 10 (sepuluh) pohon pelindung dari jenis pohon kecil atau sedang.

3.RTH Kelurahan.

RTH Kelurahan dapat disediakan dalam bentuk taman yang ditujukan untuk melayani penduduk satu kelurahan. Luas taman ini minimal 0,30 meter persegi per penduduk kelurahan, dengan luas minimal taman 9.000 meter persegi. Lokasi taman berada pada wilayah kelurahan yang bersangkutan.

Luas area yang ditanami tanaman (ruang hijau) minimal seluas $80 \%-90 \%$ dari luas taman, sisanya dapat berupa pelataran yang diperkeras sebagai tempat melakukan berbagai aktivitas. Pada taman ini selain ditanami dengan berbagai tanaman sesuai keperluan, juga terdapat minimal 25 (dua puluh lima) pohon pelindung dari jenis pohon kecil atau sedang untuk jenis taman pasif.

\subsection{Kebutuhan RTH Berdasarkan Luas Wilayah}

Pedoman penyediaan RTH dikawasan perkotaan diatur dalam Peraturan Menteri Pekerjaan Umum Nomor : 05/PRT/M/2008 yang menjelaskan sebagai berikut:

1.Ruang terbuka hijau di perkotaan terdiri dari RTH Publik dan RTH privat;

2.Proporsi RTH pada wilayah perkotaan adalah sebesar minimal $30 \%$ yang terdiri dari $20 \%$ ruang terbuka hijau publik dan $10 \%$ terdiri dari ruang terbuka hijau privat;

3. Apabila luas RTH baik publik maupun privat di kota yang bersangkutan telah memiliki total luas lebih besar dari peraturan atau perundangan yang berlaku, maka proporsi tersebut harus tetap dipertahankan keberadaannya.

Proporsi 30\% merupakan ukuran minimal untuk menjamin keseimbangan ekosistem kota, baik keseimbangan sistem hidrologi dan keseimbangan mikroklimat, maupun sistem ekologis lain yang dapat meningkatkan ketersediaan udara bersih yang diperlukan masyarakat, serta sekaligus dapat meningkatkan nilai estetika kota.

Tabel 1.

Jumlah Kebutuhan RTH di Kawasan Kota Lama Kota Kupang Berdasarkan Luas Wilayah Tahun 2015

\begin{tabular}{|c|c|c|c|c|c|c|}
\hline \multirow[b]{2}{*}{ No } & \multirow{2}{*}{$\begin{array}{l}\text { Kelu- } \\
\text { rahan }\end{array}$} & \multirow{2}{*}{$\begin{array}{c}\text { Luas } \\
\text { Wilayah } \\
(\mathrm{Km} 2)\end{array}$} & \multicolumn{3}{|c|}{ Jumlah } & \multirow{2}{*}{$\begin{array}{l}\text { Kebutuhan } \\
\text { RTH (m2) }\end{array}$} \\
\hline & & & RW & RT & Penduduk & \\
\hline 1 & LLBK & 0,20 & 5 & 10 & 732 & 600 \\
\hline 2 & Bonipoi & 0,90 & 6 & 12 & 2043 & 2700 \\
\hline 3 & Solor & 0,14 & 5 & 15 & 3150 & 420 \\
\hline & Jumlah & 1,24 & 16,00 & 37,00 & 5925,00 & 3720,00 \\
\hline
\end{tabular}

Sumber : Hasil Analisis 2016

Berdasarkan hasil analisis yang telah dilakukan, bahwa kebutuhan Luasan RTH di Kawasan Kota Lama Kota Kupang sebesar 3.720 m2

\subsection{Kebutuhan RTH Berdasarkan Jumlah Penduduk}

Untuk menentukan luas RTH berdasarkan jumlah penduduk, dilakukan dengan mengalikan antara jumlah penduduk yang dilayani dengan standar luas RTH perkapita sesuai peraturan yang berlaku (Peraturan Menteri Pekerjaan Umum No.05/PRT/M/2008).

Tabel 2.

Jumlah Kebutuhan RTH di Kawasan Kota Lama Kota Kupang Berdasarkan Jumlah Penduduk Tahun 2015

\begin{tabular}{|c|c|c|c|c|c|c|}
\hline \multirow[b]{2}{*}{ No } & \multirow{2}{*}{$\begin{array}{l}\text { Kelu- } \\
\text { rahan }\end{array}$} & \multirow{2}{*}{\begin{tabular}{|c} 
Luas \\
Wilayah \\
$(\mathrm{Km} 2)$
\end{tabular}} & \multicolumn{3}{|c|}{ Jumlah } & \multirow{2}{*}{$\begin{array}{l}\text { Kebutuhan } \\
\text { RTH (m2) }\end{array}$} \\
\hline & & & RW & RT & Penduduk & \\
\hline 1 & LLBK & 0,20 & 5 & 10 & 732 & 219,6 \\
\hline 2 & Bonipoi & 0,90 & 6 & 12 & 2043 & 612,9 \\
\hline 3 & Solor & 0,14 & 5 & 15 & 3150 & 945 \\
\hline & Jumlah & 1,24 & 16,00 & 37,00 & 5925,00 & 1777,50 \\
\hline
\end{tabular}

Sumber : Hasil Analisis 2016

Berdasarkan hasil analisis yang telah dilakukan, bahwa kebutuhan Luasan RTH di Kawasan Kota Lama Kota Kupang sebesar $1.777,5 \mathrm{~m} 2$. 


\subsection{Kebutuhan RTH Berdasarkan Kebu- tuhan Oksigen}

Kebutuhan oksigen yang dimaksud adalah oksigen yang digunakan oleh manusia, ternak dan kendaraan bermotor. Untuk mengetahui kebutuhan oksigen di suatu areal perkotaan maka perlu mengetahui jumlah penduduk yang ada. Kebutuhan oksigen untuk manusia dapat dihitung dengan asumsi bahwa manusia mengoksidasi 3000 kalori per hari dari makanan dan menggunakan sekitar 600 liter oksigen dan memproduksi sekitar 480 liter $\mathrm{CO}_{2}$ (Dewi, 2008).

3.4.1. Kebutuhan Oksigen Penduduk di Kawasan Kota Lama Kota Kupang.

Berdasarkan data dari Badan Pusat Statistik Kota Kupang tahun 2015, jumlah penduduk Kawasan Kota Lama Kota Kupang sebanyak 5.925 jiwa.

Tabel 3.

Kebutuhan Oksigen di Kawasan Kota Lama Kota Kupang Berdasarkan jumlah Penduduk/ Kelurahan

\begin{tabular}{|c|c|c|c|r|}
\hline No & Kelurahan & $\begin{array}{c}\text { Jumlah } \\
\text { Penduduk }\end{array}$ & $\begin{array}{c}\text { Kebutuhan } \\
\text { O2/hari } \\
(\mathrm{kg})\end{array}$ & $\begin{array}{c}\text { Jumlah } \\
\text { O2/hari (kg) }\end{array}$ \\
\hline 1 & LLBK & 732 & 0,86 & 629,52 \\
\hline 2 & Bonipoi & 2.043 & 0,86 & $1.756,98$ \\
\hline 3 & Solor & 3.150 & 0,86 & $2.709,00$ \\
\hline \multicolumn{2}{|c|}{ Jumlah } & 5.925 & & $5.095,50$ \\
\hline
\end{tabular}

Sumber : Hasil Analisis 2016

Berdasarkan hasil analisis yang telah dilakukan, bahwa kebutuhan oksigen menurut jumlah penduduk di Kawasan Kota Lama Kota Kupang sebesar 5.095,50 Kg/hari.

3.4.2. Kebutuhan Oksigen Kendaraan Bermotor di Kawasan Kota Lama Kota Kupang.

Konsumen terbesar oksigen selain manusia adalah kendaraan bermotor sehingga penting juga untuk diperhitungkan. Besarnya kebutuhan oksigen oleh kendaraan bermotor per hari dapat ditentukan dari jumlah konsumsi bahan bakar (bensin dan solar) per hari.
Proses kerja kendaraan bermotor adalah pengapian, proses pembakaran bahan bakarnya menggunakan oksigen. Untuk menghitung kebutuhan oksigen oleh kendaraan bermotor maka perlu diketahui jumlah dan jenis kendaraan bermotor yang ada di Kota Kupang. Berdasarkan data dari Badan Pusat Statistik Kota Kupang tahun 2016, jenis kendaraan bermotor di Kota Kupang dibedakan menjadi Sepeda Motor, Sedan/Jip/Mini Bus/Station Wagon, Bus Mini 10/16 seat/Mikrolet, Truk Tangki/Pick Up/Laktruk/Damtruk/Box, Traktor Heat.

Tabel 4.

Jumlah Kebutuhan Oksigen bagi Kendaraan Bermotor pada tahun 2015

\begin{tabular}{|c|c|c|c|c|}
\hline No & $\begin{array}{c}\text { Jenis } \\
\text { Kendaraan }\end{array}$ & $\begin{array}{c}\text { Jumlah } \\
\text { Kendaraan }\end{array}$ & $\begin{array}{l}\text { Kebutuhan } \\
\text { O2/hari (kg) }\end{array}$ & $\begin{array}{l}\text { Kebutuhan } \\
\text { O2/hari (g) }\end{array}$ \\
\hline 1 & Sepeda Motor & 27.808 & 3,03 & $3.030,00$ \\
\hline 2 & $\begin{array}{l}\text { Sedan/Jip/Mini Bus/ } \\
\text { Station Wagon }\end{array}$ & 2571,8 & 50,55 & $50.550,00$ \\
\hline 3 & $\begin{array}{l}\text { Bus Mini 10/16 seat/ } \\
\text { Mikrolet }\end{array}$ & 51 & 50,55 & $50.550,00$ \\
\hline 4 & $\begin{array}{l}\text { Truk Tangki/Pick Up/ } \\
\text { Laktruk/Damtru/ Box }\end{array}$ & 1197,2 & 84,1 & $84.100,00$ \\
\hline & Jumlah & 1.248 & 188,23 & $188.230,00$ \\
\hline
\end{tabular}

Berdasarkan hasil analisis data yang telah didapatkan, bahwa jumlah kebutuhan oksigen untuk kendaraan bermotor adalah sebesar $188.230 \mathrm{gram} / \mathrm{hari}$.

3.4.3. Kebutuhan Oksigen oleh Hewan Ternak di Kawasan Kota Lama Kota Kupang.

Kawasan Kota Lama merupakan Kawasan Perdagangan maka kebutuhan oksigen oleh Hewan Ternak dapat diabaikan.

Berdasarkan data tersebut dan dengan menggunakan data hasil penelitian yang telah ada mengenai besarnya konsumsi oksigen maka dapat dihitung jumlah kebutuhan oksigen di Kawasan Kota Lama Kota Kupang dengan persamaan sebagai berikut :

$L t=\frac{(P t+K t+T t)}{(54)(0,9375)} \mathrm{m}^{2}$ 


$$
\begin{aligned}
& \mathrm{Lt}=\frac{(5095,5+0+188.230)}{(54)(0,9375)} \mathrm{m}^{2} \\
& \mathrm{Lt}=\frac{(19.325,5)}{(50,625)} \mathrm{m}^{2}=3.818,78 \mathrm{~m}^{2}
\end{aligned}
$$

Luas RTH yang dibutuhkan pada tahun 2015 untuk menunjang kebutuhan $\mathrm{O} 2$ untuk makhluk hidup termasuk kendaraan bermotor di Kawasan Kota Lama Kota Kupang adalah seluas 3.818,78 $\mathbf{m}^{2}$ atau 0,382 Ha.

\subsection{Kebutuhan RTH Berdasarkan Netralisasi Karbon-Dioksida}

Pada proses fotosintesa tumbuhan hijau mengambil $\mathrm{CO}_{2}$ dan mengeluarkan $\mathrm{C}_{6} \mathrm{H}_{12} \mathrm{O}_{6}$ serta peranan $\mathrm{O}_{2}$ yang sangat dibutuhkan makhluk hidup. Oleh karena itu, peranan tumbuhan hijau sangat diperlukan untuk menjaring $\mathrm{CO}_{2}$ dan melepas $\mathrm{O}_{2}$ kembali ke udara. Di samping itu berbagai proses metabolisme tumbuhan hijau dapat memberikan berbagai fungsi untuk kebutuhan makhluk hidup yang dapat meningkatkan kualitas lingkungan.

Penyerap Karbon-monoksida $\left(\mathrm{CO}_{2}\right)$, beberapa jenis pohon dan tanaman tertentu memiliki manfaat luar biasa bagi ekosistem seperti pohon Mindi (Azadirachta Indica sp) mulai dari akar sebagai pesticide organic, kulit kayu dan buah sebagai bahan baku obat-obatan ayurvedia, ranting dan dahan yang kering sebagai mosquitoes-obat nyamuk, tentu saja pohonnya yang rindang besar seperti mahoni berguna sebagai pohon pelindung. Ada satu lagi fungsi utama yang kedepan; Penyerap Karbondioksida $\left(\mathrm{CO}_{2}\right)$ dan Penghasil Oksigen $\left(\mathrm{O}_{2}\right)$. Hutan secara umum dikenal sebagai penyerap gas $\mathrm{CO}_{2}$ yang cukup penting, selain dari fitoplankton, ganggang dan rumput laut di Samudera. Cahaya matahari yang memancar di kota sepanjang hari akan dimanfaat oleh hutan kota dalam fotosintesis yang berfungsi untuk mengubah gas $\mathrm{CO}_{2}$ dari $\mathrm{H}_{2} \mathrm{O}$ menjadi Karbohidrat dan Oksigen $\left(\mathrm{O}_{2}\right)$. Proses ini sangat berguna bagi manusia, sebab bila konsentrasi $\mathrm{CO}_{2}$ meningkat akan beracun bagi manusia dan menyebabkan efek rumah kaca (green-house effect). Sebaliknya proses ini menghasilkan oksigen $\left(\mathrm{O}_{2}\right)$ dan udara segar yang setiap hari sangat dibutuhkan manusia.

Setiap tahun tumbuh-tumbuhan di bumi ini mempersenyawakan sekitar 150.000 juta ton $\mathrm{CO}_{2}$ dan 25.000 juta ton hidrogen dengan membebaskan 400.000 juta ton oksigen ke atmosfer, serta menghasilkan 450.000 juta ton zat-zat organik. Setiap jam 1 ha daun-daun hijau menyerap $8 \mathrm{~kg} \mathrm{CO}_{2}$ yang ekuivalen dengan $\mathrm{CO}_{2}$ yang diembuskan oleh napas manusia sekitar 200 orang dalam waktu yang sama. Setiap pohon yang ditanam mempunyai kapasitas mendinginkan udara sama dengan rata-rata 5 pendingin udara (AC), yang dioperasikan 20 jam terus-menerus setiap harinya. Setiap 93 meter persegi pepohonan mampu menyerap kebisingan suara sebesar 8 desibel, dan setiap 1 ha pepohonan mampu menetralkan $\mathrm{CO}_{2}$ yang dikeluarkan 20 kendaraan.(Zoer'aini Djamal Irwan, 1996).

Hutan kota dianggap memiliki kelebihan dalam menyerap $\mathrm{CO}_{2}$ dibandingkan dengan taman, karena menempati hamparan yang lebih luas dari pada taman, selain dari itu biomasa hutan jauh lebih banyak dari pada taman, karena terdiri dari beberapa strata ketinggian dari yang paling rendah sampai yang tinggi pohonnya dapat mencapai 40-60 meter juga pepohonan hutan memiliki diameter tajuk dan kerapatan daun yang jauh lebih besar dari pada taman. Sesuai dengan peruntukannya, hutan kota dapat dibangun dalam beberapa bentuk. Bentuk hutan kota menurut Dahlan (2004) adalah: pekarangan, sekitar gedung, tanaman kota, tanaman atap, taman burung, bawah jalan layang, tempat parkir, sisi jalan raya dan tol, kebun binatang dan kebun raya, kuburan dan taman makam pahlawan, sempadan pantai, kiri kanan sungai dan sekitar waduk, sekitar mata air dan daerah resapan dan lapangan golf.

Fungsí hutan kota sangat tergantung kepada komposisi dan keanekaragaman jenis dari komunitas vegetasi dan tujuan perancangnya. Manfaat hutan kota menurut Direktorat Pengelolaan Daerah Aliran Sungai (DAS) dan 
Rehabilitas Departemen Kehutanan, 2001 adalah sebagai identitas kota dan estétika, pelestarian plasma nuftah, penahan dan penyaring partikel padat, penyerap $\mathrm{CO}_{2}, \mathrm{CO}_{2}$ dan penghasil $\mathrm{O}_{2}$ peredam kebisingan dan penahan angin, ameliorasi iklim dan mendukung tersedianya bahan baku kayu.

Hutan kota seharusnya tersedia dengan luasan yang cukup untuk menyerap gas-gas $\mathrm{CO}_{2}$ antropogenik, agar gas $\mathrm{CO} 2$ ambien tidak terus meningkat. Untuk itu luasan hutan kota dihitung berdasarkan pada banyaknya emisi gas $\mathrm{CO} 2$ antropogenik. Luasan optimal hutan kota diharapkan dapat mengimbangi dampak polusi $\mathrm{CO}_{2}$ antropogenik sehingga fungsinya sebagai penyerap gas $\mathrm{CO}_{2}$ dapat tercapai dengan tetap memperhatikan kenyamanan dan keamanan.

\section{Tabel 5.}

Emisi Gas $\mathrm{CO} 2$ yang dihasilkan oleh beberapa macam Bahan Bakar

\begin{tabular}{|c|c|c|c|}
\hline No. & $\begin{array}{c}\text { Jenis } \\
\text { Bahan Bakar }\end{array}$ & $\begin{array}{c}\text { Jumlah } \\
\text { Emisi }\end{array}$ & Satuan \\
\hline 1 & Bensin & 2,31 & $\mathrm{Kg} / \mathrm{Lt}$ \\
\hline 2 & Solar & 2,68 & $\mathrm{Kg} / \mathrm{Lt}$ \\
\hline 3 & Minyak Tanah & 2,52 & $\mathrm{Kg} / \mathrm{Lt}$ \\
\hline 4 & LPG & 1,51 & $\mathrm{Kg} / \mathrm{Kg}$ \\
\hline
\end{tabular}

Sumber : DEFRA (2005) dan The National Energy Foundation (2005) dalam(Dahlan, 2007)

Penelitian emisi $\mathrm{CO} 2$ yang dihitung adalah emisi $\mathrm{CO} 2$ yang dihasilkan dari pernapasan manusia dan transportasi yang terdapat di Kawasan Kota Lama

a. Pelaku Aktivitas/ Manusia.

Berdasarkan rumus perhitungan karbondioksida, maka dapat diketahui jumlah $\mathrm{CO} 2$ yang dihasilkan oleh manusia dengan asumsi semua manusia menghasilkan karbondioksida yang sama: Jumlah $\mathrm{CO} 2$ yang dihasilkan = Jumlah Penduduk $\times 0,48 \mathrm{~kg}=5.925$ jiwa $\times 0,48=$ $2.844 \mathrm{~kg}$

b.Kendaraan.

Hasil perhitungan jumlah emisi yang dikeluarkan oleh kendaraan bermotor disajikan dalam tabel berikut :
Tabel 6.

Jumlah Emisi Yang Dikeluarkan Oleh Kendaraan

\begin{tabular}{|c|l|c|c|c|c|}
\hline $\begin{array}{c}\mathrm{N} \\
\mathrm{o}\end{array}$ & \multicolumn{1}{|c|}{$\begin{array}{c}\text { Jenis } \\
\text { Kendaraan }\end{array}$} & $\begin{array}{c}\text { Jumlah } \\
\text { Kenda- } \\
\text { raan } \\
(\mathrm{smp})\end{array}$ & $\begin{array}{c}\text { FE CO2 } \\
\text { (gram/ } \\
\text { liter })\end{array}$ & $\begin{array}{c}\mathrm{K} \\
\text { (liter/100 } \\
\text { gram) }\end{array}$ & $\begin{array}{c}\text { Jumlah } \\
\text { Emisi/Q } \\
\text { (gram) }\end{array}$ \\
\hline 1 & Sepeda Motor & 579,33 & $2.597,86$ & 2,66 & $4.003 .342,74$ \\
\hline 2 & $\begin{array}{l}\text { Sedan/Jip/Mini } \\
\text { B u s / S t a t i o n } \\
\text { Wagon }\end{array}$ & 53,58 & $2.597,86$ & 11,79 & $1.641 .063,94$ \\
\hline 3 & $\begin{array}{l}\text { Bus Mini 10/16 } \\
\text { seat/Mikrolet }\end{array}$ & 1,06 & $2.924,90$ & 15,15 & $47.081,75$ \\
\hline 4 & $\begin{array}{l}\text { Truk Tangki/Pick } \\
\text { U p / L a k t r u k } \\
\text { Damtruk/Box }\end{array}$ & 24,94 & $2.924,90$ & 13,04 & $951.292,53$ \\
\hline \multicolumn{7}{|c|}{ Jumlah } & 11045,52 & & $6.642 .780,96$ \\
\hline
\end{tabular}

Dari hasil perhitungan, maka dapat diketahui bahwa jumlah $\mathrm{CO} 2$ yang dikeluarkan oleh kendaraan yaitu sebanyak 6.642.780,96 gram atau $6.642,78 \mathrm{~kg}$. Bila dibandingkan dengan jumlah emisi CO2yang dikeluarkan oleh penduduk jauh lebih besar.

c. Kebutuhan RTH berdasarkan penyerapan karbondioksida (CO2).

Berdasarkan ketentuan RTH terbuka hijau dengan berbagai jenis tanaman didalamnya seluas 1 ha dapat menyerap $900 \mathrm{~kg} / \mathrm{hr}$ karbondioksida (CO2), sehingga kebutuhan luasan RTH di Kawasan Kota Lama berdasarkan penyerapan karbondioksida yang dikeluarkan oleh penduduk dan kendaraan disajikan pada Tabel 4.7.

Tabel 7.

Kebutuhan RTH Berdasarkan Penyerapan Karbondioksida (CO2)

\begin{tabular}{|c|c|c|}
\hline Sumber & $\begin{array}{c}\text { CO2 yang } \\
\text { dihasilkan } \\
(\mathrm{kg})\end{array}$ & $\begin{array}{c}\text { Kebutuhan } \\
\text { Luasan } \\
\text { RTH }(\mathrm{km} 2)\end{array}$ \\
\hline $\begin{array}{c}\text { Pelaku/Aktifitas } \\
\text { Penduduk }\end{array}$ & $2.844,00$ & $3.160,00$ \\
\hline Kendaraan & $6.642,78$ & $7.380,87$ \\
\hline Jumlah & $9.486,78$ & $10.540,87$ \\
\hline
\end{tabular}


Bila dilihat dari kebutuhan RTH berdasarkan penyerapan Karbondioksida Kawasan Kota Lama membutuhkan Ruang Terbuka Hijau jauh lebih besar yaitu seluas 10.540,87 atau $85 \%$ dari total luas wilayah Kawasan Kota Lama.

\subsection{Kebutuhan RTH Kawasan Kota Lama Kota Kupang}

Berdasarkan hasil analisis kebutuhan RTH di Kota Kupang dari berbagai pendekatan menunjukkan :

1.Undang-undang No 26 tahun 2007 tentang Penataan Ruang. Proporsi RTH pada wilayah perkotaan paling sedikit 30\% (tiga puluh persen) dari luas wilayah kota, yang terdiri dari $20 \%$ ruang terbuka hijau publik dan $10 \%$ ruang terbuka privat. Jika hasil perhitungan lebih kecil dari $30 \%$, maka kebutuhan RTH yang digunakan tetap $30 \%$, sedangkan jika hasil perhitungan lebih besar dari $30 \%$ maka angka tersebut yang dijadikan target pemenuhan luas RTH. Peraturan Menteri Pekerjaan Umum Nomor : 05/PRT/M/2008 tentang Pedoman penyediaan dan pemanfaatan Ruang terbuka hijau di kawasan perkotaan, standar untuk Ruang Terbuka Hijau di Kawasan Kota
Lama Kota Kupang adalah sebesar 30\% dari Luas wilayah Kawasan Kota Lama Kota Kupang. Luas Kawasan Kota Lama kota kupang adalah 1,24 $\mathrm{Km}^{2}$ maka Kebutuhan Ruang Terbuka Hijau sesuai dngan standar yaitu $0,372 \mathrm{Ha}$ yang terdiri dari $0,248 \mathrm{Ha}$ Ruang Terbuka Hijau Publik, 0,124 Ha Ruang Terbuka Hijau Privat.

2.Sesuai dengan jumlah penduduk yang ada pada tahun 2015 kebutuhan RTH di Kawasan Kota Lama Kota Kupang adalah 1777,5 m² atau $0,178 \mathrm{Ha}$

3.Luas RTH yang dibutuhkan pada tahun 2015 untuk menunjang kebutuhan $\mathrm{O} 2$ untuk makhluk hidup termasuk kendaraan bermotor di Kota Kupang adalah seluas 3.818,78 $\mathrm{m}^{2}$ atau $0,382 \mathrm{Ha}$.

4.Kebutuhan RTH berdasarkan penyerapan Karbondioksida Kawasan Kota Lama membutuhkan Ruang Terbuka Hijau jauh lebih besar yaitu seluas $10.540,87$ atau 1,054 $\mathrm{Ha}$.

Untuk mengetahui rekapitulasi analisa kebutuhan RTH di Kawasan Kota Lama Kota Kupang tahun 2015 berdasarkan Luas Wilayah, Jumlah Penduduk, Kebutuhan O2, Netralitas $\mathrm{CO} 2$ dan dapat dilihat pada tabel 4.8.

Tabel 8.

Rekapitulasi Kebutuhan RTH di Kawasan Kota Lama Kota Kupang tahun 2015

\begin{tabular}{|c|c|c|c|c|c|c|c|}
\hline \multirow[b]{2}{*}{ No } & \multirow[b]{2}{*}{ Kelurahan } & \multirow{2}{*}{$\begin{array}{c}\text { Luas } \\
\text { Wilayah } \\
\text { (Ha) }\end{array}$} & \multirow[b]{2}{*}{$\begin{array}{c}\text { Jumlah } \\
\text { Penduduk }\end{array}$} & \multicolumn{3}{|c|}{ Kebutuhan RTH (Ha) } & \multirow[b]{2}{*}{$\begin{array}{c}\text { Netralitas } \\
\mathrm{CO} 2\end{array}$} \\
\hline & & & & $\begin{array}{c}\text { Luas } \\
\text { Wilayah }\end{array}$ & $\begin{array}{c}\text { Jumlah } \\
\text { Penduduk }\end{array}$ & $\begin{array}{c}\text { Kebutuhan } \\
\text { O2 }\end{array}$ & \\
\hline 1 & LLBK & 0,20 & 732 & 0,06 & 0,02 & \multirow{3}{*}{0,38} & \multirow{3}{*}{1,05} \\
\hline 2 & Bonipoi & 0,90 & 2043 & 0,27 & 0,06 & & \\
\hline 3 & Solor & 0,14 & 3150 & 0,04 & 0,09 & & \\
\hline & Jumlah & 1,24 & 5925,00 & 0,37 & 0,18 & 0,38 & 1,05 \\
\hline
\end{tabular}

\subsection{Kondisi Eksisting RTH Dikawasan Kota Lama Kota Kupang}

Berdasarkan hasil pengamatan, RTH Publik di Kelurahan LLBK Kota Kupang saat ini hanya sebesar 0,14 Ha atau $\mathbf{1 1 , 2 9 \%}$ dari luasan total wilayah. Luasan RTH Publik ini menunjukkan belum terpenuhinya luasan minimal $20 \%$ RTH Publik di perkotaan sesuai dengan UU No 26 Tahun 2007. Luasan minimal RTH Publik yang dibutuhkan adalah $20 \%$ x 1,24 Ha = 0,25 Ha.

Kondisi saat ini menunjukkan bahwa RTH Publik di Kelurahan LLBK hanya terdapat di 
RT 07 (taman rekreasi pantai kopan, taman tugu terminal), RT 06 (sepanjang DAS Selam), RT 10 (Gereja Kota Kupang), RT 04 (parkiran terbuka, dan pesisir pantai).

Kondisi ini disebabkan oleh beberapa hal yang diuraikan sebagai berikut:

a.Belum adanya aturan dan kebijakan pemerintah daerah mengenai pengalokasian area dan luasan RTH Publik di Kawasan Kota Lama. Dalam Perda nomor 12 tahun 2011 hanya diatur luas RTH untuk BWK I seluas $329,75 \mathrm{Ha}$.

b.Lahan-lahan di Kawasan Kota Lama dengan peruntukkan bangunan untuk jasa dan komersil dibangun dengan tingkat kepadatan tinggi, padahal sesuai dengan ketentuan perda nomor 12 tahun 2011 disyaratkan : KDB paling tinggi sebesar 80 persen; KLB paling rendah sebesar 8,0; KDH paling rendah sebesar 15 persen; GSB dengan ketentuan 1/2 rumija; dan GSS paling rendah sesuai ketentuan yang berlaku.

c.Adanya pemukiman dan pertokoan di area sempadan sungai dan pantai yang seharusnya menjadi lahan konservasi

Luasan RTH Privat di Kawasan Kota Lama terdiri dari RTH Pekarangan sebesar $745 \mathrm{~m}^{2}$ dan RTH Taman Atap sebesar $200 \mathrm{~m}^{2}$ dengan luas total sebesar 0,09 Ha (RTH Privat di) atau $\mathbf{7 , 2 5} \%$ dari luasan total wilayah. Luasan RTH Privat ini menunjukkan belum terpenuhinya luasan minimal $10 \%$ RTH Prifat di perkotaan sesuai dengan UU No 26 Tahun 2007. Luasan minimal RTH Privat yang dibutuhkan adalah $10 \% \times 1,25 \mathrm{Ha}=\mathbf{0 , 1 2} \mathrm{Ha}$.

\subsection{Pengembangan RTH Di Kawasan Kota Lama Kota Kupang}

Salah satu langkah penting dalam pengembangan RTH Kota Kupang adalah mengawali dengan pernyataan tentang tujuan pengembangan. Mencapai luas RTH sebesar 30\% dari luas wilayah kota seperti digariskan UUPR 26/ 2007 bukanlah suatu tujuan yang cukup jelas. Lebih tepat, bila nilai $30 \%$ luas wilayah kota tersebut menjadi suatu indikator keberhasilan pengembangan RTH di Kawasan Kota Lama Kota Kupang.

Beberapa konsep yang diadopsi oleh Pemerintah Kota Kupang dalam rangka pengembangan ruang terbuka hijau di kawasan Kota Lama adalah sebagai berikut :

1.Terjadinya Perubahan Paradigma Perencanaan Ruang Terbuka Hijau, sebagai berikut: a.Paradigma Perencanaan Ruang Terbuka Hijau Lama :

- Lebih mengedepankan Nilai Estetis dan Visual secara Fisik.

- Keberadaan Ruang Hijau lebih berkesan sebagai suatu Simbol.

b.Paradigma Perencanaan Ruang Terbuka Hijau baru :

- Tata Ruang Hijau direncanakan untuk :

- Mengembalikan Fungsi Ekologi dan Ekosistem Ruang Kota.

- Mengoptimalkan Fungsi Estetis dan Lansekap.

- Menciptakan Aktivitas Sosial Masyarakat di tingkat Lingkungan.

- Membuka peluang Ekonomi Produktif bagi masyarakat kecil.

- Ruang Terbuka Hijau dapat menciptakan aktivitas dan menjadi bagian dari Fungsi Aktivitas Ruang Publik.

- Harus terjadi interaksi antara Lokasi, Fungsi dan Bentuk Ruang Terbuka Hijau dengan Activity Support di ruang kota / kawasan.

- Ruang Hijau dapat merubah Fungsi Space menjadi Place.

2.Tahapan Konsep Pembangunan Ruang Terbuka Hijau, sebagai berikut :

a. Tahap Penyediaan Ruang Terbuka (Open Space) di Wilayah Perkotaan, yaitu sebuah Area berbentuk Hamparan / Jalur Memanjang tanpa bangunan.

b.Tahap Penghijauan pada area Ruang Terbuka dengan cara pengisian Vegetasi pada Kawasan Konservasi / Lindung dan Kawasan Budidaya / Terbangun menjadi area Ruang Terbuka Hijau (Green Space).

c. Tahap Optimalisasi Ruang Terbuka Hijau, disesuaikan dengan Fungsi yang akan 
dicapai dalam wilayah koridor Kota melalui Program Ruang Hijau Kota (Green City / Green Cities), yaitu area kota / koridor kota yang ditanami dengan Vegetasi tertentu, dengan Bentuk, Fungsi dan pada Lokasi tertentu disesuaikan dengan kebutuhan.

d. Tahap Perencanaan, Penataan dan Pengelolaan Ruang Terbuka Hijau pada Spot-spot tertentu yang berskala lebih kecil sebagai bagian perencanaan detail kota melalui Program Gardening System, yang bertujuan untuk mengangkat Potensi site yang sudah ada, Menutupi Sisi Buruk Site dan Optimalisasi Fungsi (baik secara ekologi, ekonomi maupun estetika lansekap).

3.Strategi yang akan dicapai dalam Pengembangan dan Pengelolaan Ruang Terbuka Hijau a.Secara Spasial :

- Ruang Terbuka Hijau menjadi bagian dari Fungsi Aktivitas Ruang Publik.

- Terjadi interaksi antara Lokasi, Fungsi dan Bentuk Ruang Terbuka Hijau dengan Activity Support di ruang kota.

- Ruang Hijau mampu mengakomodasi Fungsi Space menjadi Place.

b.Secara Tentatif :

- Mengembalikan Fungsi Ekologi dan Ekosistem Ruang Kota dengan jalan Optimalisasi Lahan untuk Perbaikan Lingkungan.

- Mengoptimalkan Fungsi Estetis dan Lansekap Kota dengan cara Mengoptimalkan Potensi Site serta Menutupi Kondisi Site yang Buruk.

- Menciptakan \& Mendukung Aktivitas Sosial Masyarakat di tingkat Lingkungan.

- Membuka \& menciptakan peluang Ekonomi Produktif bagi masyarakat kecil, terutama di lingkungan perumahan dan permukiman.

Sedangkan untuk pendekatan yang digunakan dalam pengembangan ruang terbuka hijau pada zona ruang masing-masing berbeda sesuai dengan peran dan fungsi dari zona tersebut. Pendekatan yang digunakan adalah sebagai berikut :
1.Pendekatan Dan Konsep Ruang Terbuka Hijau Pada Kawasan Permukiman.

a.Permukiman Kepadatan Tinggi

- Pendekatan Estetis Lansekap, Konsep : Kenyamanan, Estetika Lingkungan, Suplai Oksigen.

- Pendekatan Ekologis : Reduksi Polutan, Mengatasi Genangan Air.

- Pendekatan Ekonomis : Menghasilkan Nilai Ekonomi Produktif.

b.Permukiman Kepadatan Sedang

- Pendekatan Estetis Lansekap, Konsep : Kenyamanan, Estetika Lingkungan, Suplai Oksigen.

- Pendekatan Ekologis : Reduksi Polutan, Konservasi Air.

- Pendekatan Ekonomis : Menghasilkan Nilai Ekonomi Produktif.

c. Permukiman Kepadatan Rendah

- Pendekatan Estetis Lansekap, Konsep : Kenyamanan, Estetika Lingkungan, Suplai Oksigen.

- Pendekatan Ekologis : Penahan Erosi dan Longsor, Konservasi Air.

- Pendekatan Ekonomis : Menghasilkan Nilai Ekonomi Produktif.

2.Pendekatan Dan Konsep Ruang Terbuka Hijau Pada Kawasan Perkantoran Dan Fasilitas Umum.

- Pendekatan Estetis Lansekap : Kenyamanan, Estetika Lingkungan, Identitas Bangunan, Suplai Oksigen.

- Pendekatan Ekologis : Reduksi Polutan, Reduksi Kebisingan.

3.Pendekatan Dan Konsep Ruang Terbuka Hijau Pada Kawasan Perdagangan Dan Jasa Komersial.

- Pendekatan Estetis Lansekap : Kenyamanan, Estetika Lingkungan, Identitas Bangunan, Suplai Oksigen.

- Pendekatan Ekologis : Reduksi Polutan, Reduksi Kebisingan.

- Pendekatan Estetis Lansekap : Estetika Lingkungan, Identitas Bangunan, Suplai Oksigen.

- Pendekatan Ekologis : Reduksi Polutan, Reduksi Kebisingan. 
4.Pendekatan Dan Konsep Ruang Terbuka Hijau Pada Kawasan Lindung / Konservasi.

a.Pendekatan Estetis Lansekap, Konsep : Kenyamanan, Suplai Oksigen.

b.Pendekatan Ekologis : Penahan Erosi dan Longsor, Konservasi Air.

c. Pendekatan Ekonomis : Menghasilkan Nilai Ekonomi Produktif.

\section{KESIMPULAN DAN SARAN}

\subsection{Kesimpulan}

Hasil penelitian menunjukkan bahwa RTH yang terdapat di Kelurahan LLBK hanya terdiri dari a). RTH Publik berupa : Taman kota pantai Kopan, Taman Tugu, Terminal, Halaman Gereja Kota Kupang, Parkiran terbuka Jalan Siliwangi,
Sempadan Pantai, Sempadan Sungai. Luasan RTH Publik mencapai 0,14 Ha atau sebesar 11,29\% dari luas Kawasan Kota Lama. Sedangkan berdasarkan pedoman dari UU No. 26 tahun 2007 maka luas RTH Publik yang dibutuhkan sebesar $20 \%$ adalah 0,24 Ha ; b). RTH Privat : Pekarangan seluas $745 \mathrm{~m}^{2}$ dan Taman Atap sebesar $200 \mathrm{~m}^{2}=945 \mathrm{~m}^{2}$ atau $\mathbf{0 , 0 9 1}$ Ha atau sebesar 7,25\% dari luas Kawasan Kota Lama. Sedangkan berdasarkan pedoman dari UU No. 26 tahun 2007 maka luas RTH Privat yang dibutuhkan sebesar $10 \%$ adalah seluas 0,12 Ha

Adapun kebutuhan luasan RTH di Kawasan Kota Lama dapat dijelaskan melalui tabel 4.9 berikut ini :

Tabel 9.

Kebutuhan Luasan RTH di Kawasan Kota Lama Kota Kupang tahun 2015

\begin{tabular}{|c|c|c|c|c|c|c|c|}
\hline \multirow{2}{*}{ No } & \multirow{2}{*}{ Kelurahan } & \multirow{2}{*}{$\begin{array}{c}\text { Luas } \\
\text { Wilayah }\end{array}$} & \multirow{2}{*}{$\begin{array}{c}\text { Jumlah } \\
\text { Penduduk }\end{array}$} & $\begin{array}{c}\text { Luas } \\
\text { Wilayah }\end{array}$ & $\begin{array}{c}\text { Jumlah } \\
\text { Penduduk }\end{array}$ & $\begin{array}{c}\text { Kebutuhan } \\
\text { O2 }\end{array}$ & \multirow{2}{*}{$\begin{array}{c}\text { Netralitas } \\
\text { CO2 }\end{array}$} \\
\hline 1 & LLBK & 0,20 & 732 & 0,06 & 0,02 & & \\
\hline 2 & Bonipoi & 0,90 & 2043 & 0,27 & 0,06 & 0,38 & 1,05 \\
\hline 3 & Solor & 0,14 & 3150 & 0,04 & 0,09 & & \\
\hline & Jumlah & $\mathbf{1 , 2 4}$ & $\mathbf{5 9 2 5 , 0 0}$ & $\mathbf{0 , 3 7}$ & $\mathbf{0 , 1 8}$ & $\mathbf{0 , 3 8}$ & $\mathbf{1 , 0 5}$ \\
\hline
\end{tabular}

\subsection{Saran}

1.Konsep pengelolaan dan perencanaan Ruang Terbuka Hijau Kawasan Kota Lama perlu melihat keberadaan Kawasan Kota Lama sebagai kawasan perekonomian/perdagangan, jasa dan pariwisata, kawasan pesisir, kota tua dan cagar budaya.

2.RTH Kawasan Kota Lama Kota Kupang perlu mendapat perhatian dari Pemerintah Kota Kupang dan dirancang serta dikelola dengan memperhatikan karakter lokal seperti kehadiran vegetasi khas daerah pesisir.

3.Dominasi vegetasi dalam RTH di Kawasan Kota Lama Kota Kupang sangat menentukan dalam keberhasilan fungsi RTH sebagai pengatur iklim mikro kota dan menjaga keseimbangan hidrologis. Dominasi vegetasi lebih khusus pada kawasan seperti sempadan pantai.

\section{DAFTAR PUSTAKA}

Anjelicus, P.J. 2008. Prinsip-Prinsip Perancangan Ruang Terbuka Hijau Di Kota Kupang. Tesis PWK ITB. Bandung. 145 Hal.

Anonim. 2005. Ruang Terbuka Hijau (RTH) Wilayah Perkotaan, Makalah Lokakarya Pengembangan Sistem RTH Di Perkotaan. Lab. Perencanaan Lanskap Departemen Arsitektur Lanskap Fakultas Pertanian IPB. Bogor. 11 Hal. 
Dewi, M.S. 2008. Studi Kebutuhan Ruang Terbuka Hijau Untuk Menurunkan Tingkat Pencemaran Udara Oleh Emisi Kendaraan Bermotor Di Kota Tangerang. Tesis PWK ITB. Bandung. 119 Hal.

Hakim, R. 2002. Komponen Perancangan Arsitektur Lansekap. Bumi Aksara. Jakarta.

Hardiansah, E.C. dan M.M, Dhani. 2011. Most Livable City Index : Pendekatan Baru dalam Mengukur Tingkat Kenyamanan Kota. Buletin Tata Ruang Edisi JuliAgustus. Badan Koordinasi Penataan Ruang Nasional. Hal 28-31.

Laurie, I.C. 1979. Nature In Cities. The Natural Environment In The Design And Development Of Urban Green Space. John Wiley \& Sons. New York. 390 Hal.
Peraturan Menteri Pekerjaan Umum Nomor 05/ PRT/M/2008 Tentang Pedoman Penyediaan dan Pemanfaatan Ruang Terbuka Hijau Di Kawasan Perkotaan. 63 Hal.

Permendagri Nomor 1 Tahun 2007 Tentang Penataan Ruang Terbuka Hijau Kawasan Perkotaan. 8 Hal.

Prasetijaningsih, C.D. 2012. Ruang Terbuka Hijau dalam Kota yang sehat. Buletin Tata Ruang Edisi Januari-Februari. Badan Koordinasi Penataan Ruang Nasional. Hal 19-26.

Purnomohadi, N. 2006. Ruang Terbuka Hijau Sebagai Unsur Utama Tata Ruang Kota. Dirjen Penataan Ruang PU. Jakarta. 320 Hal. 